\title{
Post-marketing withdrawal of anti-obesity medicinal products because of adverse drug reactions: a systematic review
}

\author{
Igho J. Onakpoya ${ }^{1 *}$, Carl J. Heneghan ${ }^{2}$ and Jeffrey K. Aronson ${ }^{1}$
}

\begin{abstract}
Background: We identified anti-obesity medications withdrawn since 1950 because of adverse drug reactions after regulatory approval, and examined the evidence used to support such withdrawals, investigated the mechanisms of the adverse reactions, and explored the trends over time.

Methods: We conducted searches in PubMed, the World Health Organization database of drugs, the websites of drug regulatory authorities, and selected full texts, and we hand searched references in retrieved documents. We included anti-obesity medications that were withdrawn between 1950 and December 2015 and assessed the levels of evidence used for making withdrawal decisions using the Oxford Centre for Evidence-Based Medicine criteria.

Results: We identified 25 anti-obesity medications withdrawn between 1964 and 2009; 23 of these were centrally acting, via monoamine neurotransmitters. Case reports were cited as evidence for withdrawal in $80 \%$ of instances. Psychiatric disturbances, cardiotoxicity (mainly attributable to re-uptake inhibitors), and drug abuse or dependence (mainly attributable to neurotransmitter releasing agents) together accounted for $83 \%$ of withdrawals. Deaths were reportedly associated with seven products (28\%). In almost half of the cases, the withdrawals occurred within 2 years of the first report of an adverse reaction.

Conclusions: Most of the drugs that affect monoamine neurotransmitters licensed for the treatment of obesity over the past 65 years have been withdrawn because of adverse reactions. The reasons for withdrawal raise concerns about the wisdom of using pharmacological agents that target monoamine neurotransmitters in managing obesity. Greater transparency in the assessment of harms from anti-obesity medications is therefore warranted.
\end{abstract}

Keywords: Obesity, Drug withdrawal, Adverse drug reaction, Systematic review

\section{Background}

The prevalence of corpulence and obesity has more than tripled in the last decade [1], giving rise to substantially increased healthcare costs $[2,3]$. According to the World Health Organization (WHO), corpulence and obesity are the fifth leading cause of mortality worldwide [4]. Strategies to reduce weight include diet and lifestyle adjustments, behavioural techniques, and drug therapy [5]; however, they have had little effect on the growing obesity epidemic.

\footnotetext{
* Correspondence: igho.onakpoya@kellogg.ox.ac.uk

${ }^{1}$ Nuffield Department of Primary Care Health Sciences, University of Oxford, Centre for Evidence-Based Medicine, Gibson Building, Radcliffe Observatory Quarter, Oxford OX2 6GG, UK

Full list of author information is available at the end of the article
}

Modern drug therapy for obesity treatment began in 1933 with the use of 2,4-dinitrophenol (2,4-DNP), a thermogenic agent, for weight reduction [6]. However, its use was associated with serious adverse reactions, and the US Food and Drug Administration (FDA) banned it in 1938 [7]. In the late 1930s, drugs acting on monoamine neurotransmitters, prescribed as appetite suppressants, were introduced [8]. One such drug, Hydrin (amphetamine), gained FDA approval under controversial circumstances, because the FDA's then acting medical director served as a consultant to the Council on Pharmacy and Chemistry of the American Medical Association (AMA) [9]. The council later withdrew its approval of Hydrin, citing lack of evidence on harms 
[10]. This was followed by the development of other anti-obesity medications, mainly congeners of amphetamine and monoamine re-uptake inhibitors [11].

In recent years, there has been a growing focus on the development of novel therapies for the treatment of obesity [12], including drug combinations, a few of which have recently gained marketing approvals from regulatory authorities [13].

However, at the same time several anti-obesity products have been withdrawn from the market after approval because of adverse reactions [14]. To date, the patterns of and reasons for withdrawal of anti-obesity products have not been systematically analysed. Therefore, our objectives were to identify anti-obesity products withdrawn from the market because of adverse reactions, to examine the evidence used for withdrawals, determine the mechanism through which the adverse reactions occurred, and explore the patterns in withdrawal over time.

\section{Methods}

\section{Search strategy}

We searched for anti-obesity medications that had been withdrawn from the market after regulatory approval because of adverse drug reactions between 1950 and December 2015 from the following sources:

- WHO database of Consolidated List of Products whose consumption and/or sale have been banned, withdrawn, severely restricted, or not approved by governments (issues $6,8,12$, and 14)

- Regulatory news sections of WHO Drug Information (volumes 1-29)

- WHO Pharmaceuticals Newsletter (1997-2015)

- UK Medicines and Healthcare products Regulatory Agency (MHRA) website

- US FDA website

- Database of withdrawn drugs of the European Medicines Agency (EMA)

For each withdrawn anti-obesity medicine identified, we searched the following sources for the first reported adverse drug reaction: PubMed, Medline, Google Scholar, Meyler's Side Effects of Drugs and the Side Effects of Drugs Annuals 1-36, and Stephens' Detection of New Adverse Drug Reactions, 5th edition. Search terms used included "anti-obesity", "withdrawal", "fatal"", "adverse reaction", "adverse event", "toxicity", "voluntary recall", "suspension", "prohibition", "banned", "remov", "revoke"", and "discontinued". (See Additional file 1 for extended search lists of websites and other sources accessed, together with search strategies used for searching scientific databases.) If we could not find information for an anti-obesity medication when using its chemical name for searches, we used trade or code names. We also hand searched references in retrieved full texts for earlier reports of adverse reactions. If an article contained information about an earlier reported date, that date was chosen as the first adverse reaction date. If an anti-obesity medicine was withdrawn because of two or more adverse reactions, we used the date of the first reported reaction.

\section{Inclusion/exclusion criteria}

To be included in the review, an anti-obesity medicinal product must have been withdrawn from the market because of reports of suspected adverse reaction(s) or problems related to hazards or harms. We excluded anti-obesity medicines for which there was documented regulatory evidence that they had been voluntarily withdrawn by marketing authorization holders (MAHs) solely for commercial reasons. We also excluded herbal, non-human, and non-prescription medicines (i.e. medicines that were not approved via the conventional regulatory pathway for drug licensing) used as weight loss products.

\section{Assessing the types of evidence}

We documented the highest level of available evidence before the year of first withdrawal of anti-obesity medicines, based on the Oxford Centre for Evidence-Based Medicine (OCEBM) criteria [15], which rank the levels of evidence of harms as follows: Level 1, systematic review (highest); Level 2, randomized clinical trial; Level 3, non-randomized cohort or follow-up studies; Level 4, caseseries or case-control studies; and Level 5, mechanismbased reasoning (lowest). One reviewer (IJO) documented the levels of evidence, which were independently verified by a second reviewer (JKA). Disagreements were resolved through discussion.

\section{Data extraction}

For each withdrawn anti-obesity product, we extracted data on the marketing authorization or launch date (or the date of first recorded use); the drug class, mechanism of action, and therapeutic indication(s) [16]; the year an adverse reaction related to the reason for withdrawal was first reported; the year of first withdrawal; the country or countries of withdrawal; and the reported mechanism by which the drug caused the adverse reaction. One reviewer (IJO) extracted the data, and a second reviewer (JKA) verified them independently. Discrepancies were resolved by discussion.

\section{Statistical analyses}

We used summary tables to document the intervals between launch year and the year of first report of an adverse drug reaction, the interval between launch year 
and the year of first withdrawal, and the interval between the first report of an adverse drug reaction and the year of first withdrawal. Because these intervals were skewed, we used medians and interquartile ranges (IQRs). We also compared intervals to reports of adverse reactions and withdrawals between products based on their mechanistic actions. Fisher's exact test was used to test for differences in the proportions of withdrawals based on the pharmacological mechanisms of action; a $P$ value of $<0.05$ was considered statistically significant.

\section{Results}

We identified 47 withdrawn medicinal products used for treating obesity (Additional file 2). We excluded 11 products because they were plant-based "herbal" products and another 11 because they were discontinued before being granted regulatory approval. This left 25 products for inclusion. Two of the products, fenfluramine and dexfenfluramine, were withdrawn worldwide. Of the remaining 23 products, 19 were withdrawn in Europe, 11 in Asia, 9 in South America, 8 in North America, 4 in Africa, and 1 in Australasia (Table 1).

Of the 25 withdrawn products, 22 (92\%) were appetite suppressants acting on monoamine neurotransmitters (Table 1). Their primary mechanisms of action were through central effects on adrenoceptors and dopamine receptors (8); adrenoceptors, dopamine receptors, and serotonin receptors (5); serotonin receptors only (6); adrenoceptors only (1); adrenoceptors and serotonin receptors (1); and serotonin and dopamine receptors (1). One drug acted on cannabinoid receptors, one by stimulating bile acid secretion, and one by attachment to thyroid hormone binding proteins.

Case reports (Level 4 evidence) were cited as evidence for withdrawal in 20 instances (80\%), and Level 3 evidence in two instances (8\%) (Table 1). The withdrawal of one product, chlorphentermine, was based on evidence from animal studies. Cardiotoxicity accounted for 8 withdrawals (32\%) and psychiatric adverse reactions for 7 (28\%). Drug abuse or dependence was cited in more than half of the withdrawals (13 cases, 52\%), and drugattributed deaths were associated with the withdrawal of 7 products $(28 \%)$.

Of the 23 withdrawn products acting via monoamine neurotransmitters, 8 were re-uptake inhibitors and 14 were releasing agents (Table 1). One product, rimonabant, was an antagonist and inverse agonist at cannabinoid receptors. The releasing agents were significantly more likely to be withdrawn because of drug abuse compared with the re-uptake inhibitors $(P=0.002)$; the re-uptake inhibitors were significantly more likely to be withdrawn because of cardiovascular adverse reactions compared with the releasing agents $(P=0.0004)$. Psychiatric adverse reactions were not significantly different between the two groups of agents.

The longest interval between launch and the first report of an adverse drug reaction was 38 years (norpseudoephedrine), while the shortest interval was less than 1 year (rimonabant). The median interval between launch and first report of an adverse drug reaction was 10 years (IQR $=3$ to 20 years). In $24 \%$ of cases, first reports of the adverse drug reactions in the literature occurred within 2 years. Overall, there was a shortening in the interval between launch and first published reports of adverse drug reactions. The interval between launch and first reports of adverse reactions was considerably shorter with the re-uptake inhibitors than with the releasing agents: 5.5 years (IQR $=1.3$ to 13 years) versus 18 years (IQR $=5.8$ to 28 years); see Table 2 . The median interval to first reports of adverse reactions was considerably shorter when there was cardiotoxicity compared with drug abuse: 5.5 years (IQR $=1.3$ to 15 years) versus 15 years (IQR $=5.5$ to 24 years).

The longest interval between first report and first withdrawal was 23 years (phenmetrazine), while the shortest interval was less than 1 year in three cases (aminorex fumarate, cloforex, and iodinated casein; Table 1). The median interval between first report and first withdrawal was 11 years (IQR $=0$ to 23 years). Figure 1 shows that the more recent the launch year, the faster the product was withdrawn from the market following adverse reaction reports. In $48 \%$ of cases, withdrawals occurred within 2 years of the first adverse drug reaction (ADR) reports. When deaths were attributed to the products, the median interval to withdrawal was 1 year. The median time to withdrawal following reports of adverse reactions was shorter with the re-uptake inhibitors than the releasing agents: 1 year (IQR $=0$ to 12 years) versus 5 years (IQR $=2$ to 16 years); Table 2 . The median time to withdrawal following reports of adverse reactions was considerably longer with drugs that caused abuse or dependence than with drugs that caused cardiotoxicity: 7 years $(\mathrm{IQR}=3.5$ to 17 years) versus 0.5 year $(\mathrm{IQR}=0$ to 5 years).

\section{Discussion}

We have identified 25 anti-obesity medications that were withdrawn after marketing between 1964 and 2009, 23 of which had centrally acting mechanisms via monoamine neurotransmitters. The evidence for withdrawal in about $80 \%$ of cases was anecdotal reports. Cardiovascular and psychiatric adverse drug reactions and drug abuse and dependence together accounted for $83 \%$ of the withdrawals. In $28 \%$ of cases, deaths were attributed to the products. Among the centrally acting agents, re-uptake inhibitors were more likely to be withdrawn because of cardiotoxicity, while the neurotransmitter releasers were more likely 
Table 1 List of anti-obesity drugs withdrawn from the market because of adverse drug reactions

\begin{tabular}{|c|c|c|c|c|c|c|c|c|}
\hline Medicinal product & $\begin{array}{l}\text { Primary mechanism } \\
\text { of action }\end{array}$ & Therapeutic indication & $\begin{array}{l}\text { Launch } \\
\text { date }\end{array}$ & $\begin{array}{l}\text { Year of first } \\
\text { ADR report }\end{array}$ & $\begin{array}{l}\text { Year first } \\
\text { withdrawn }\end{array}$ & Countries withdrawn & Primary reason for withdrawal & $\begin{array}{l}\text { Level of } \\
\text { evidence }^{\mathrm{a}}\end{array}$ \\
\hline Amfepramone (diethylpropion) $)^{b}$ & SNDRA & Obesity & 1957 & 1974 & 1975 & $\begin{array}{l}\text { Turkey, Sweden, Oman, UAE, Norway, } \\
\text { Venezuela, EU, France, UK, Brazil }\end{array}$ & Cardiotoxicity & 4 \\
\hline Amphetamine & SNDRA & Obesity, narcolepsy & 1939 & 1957 & 1973 & USA, UAE, Turkey, Oman, Malaysia, Nigeria & Drug abuse and dependence & 4 \\
\hline Aminorex fumarate ${ }^{c}$ & SRI & Obesity & 1962 & 1967 & 1967 & Germany, Venezuela, Switzerland, Austria & Cardiotoxicity & 4 \\
\hline Benfluorex ${ }^{c}$ & SRI & Obesity, diabetes & 1976 & 2003 & 2009 & Europe & Cardiotoxicity & 3 \\
\hline Chlorphentermine & SRI & Obesity & 1962 & & 1969 & Germany, Venezuela & Cardiotoxicity & 5 \\
\hline Clobenzorex & SNDRA & Obesity & 1966 & 1986 & 2000 & Mauritius, USA, Oman & Drug abuse, psychiatric & 4 \\
\hline Cloforex & $\mathrm{SRI}$ & Obesity & 1965 & 1967 & 1967 & Germany, Sweden, Venezuela & Cardiotoxicity & 4 \\
\hline Cyclovalone + retinol + tiratricol & Bile acid secretion & $\begin{array}{l}\text { Hyperlipidemia, } \\
\text { dyspepsia, obesity }\end{array}$ & 1964 & 1984 & 1988 & France & Liver toxicity & 4 \\
\hline Dexfenfluramine & SRI & Obesity & 1995 & 1995 & 1997 & Worldwide & Cardiotoxicity & 4 \\
\hline Fenbutrazate & NDRA & Obesity & 1957 & 1963 & 1969 & Europe & Drug abuse, psychiatric & 2 \\
\hline Fenfluramine ${ }^{c}$ & SRI & Obesity & 1973 & 1981 & 1997 & Worldwide & Cardiotoxicity & 3 \\
\hline Fenproporex (perphoxene) & NRA & $\begin{array}{l}\text { Obesity, narcolepsy, } \\
\text { ADHD }\end{array}$ & 1966 & 1997 & 1999 & Europe, Brazil & Drug abuse, psychiatric & 4 \\
\hline lodinated casein strophanthin & Thyroxine analogue & Obesity & 1944 & 1964 & 1964 & USA & Endocrine, metabolism & 4 \\
\hline Levamphetamine & SNDRA & Obesity & 1944 & 1954 & 1973 & USA, Oman, UAE & Drug abuse and dependence & 4 \\
\hline Mazindol & NRDA & Obesity & 1970 & 1980 & 1987 & Oman, Brazil & $\begin{array}{l}\text { Drug abuse, psychiatric } \\
\text { (interaction with lithium) }\end{array}$ & 4 \\
\hline $\begin{array}{l}\text { Mefenorex } \\
\text { (methylphenethylamine) }\end{array}$ & SNDRA & Obesity & 1966 & 1995 & 1999 & Europe, Oman & Drug abuse, psychiatric & 4 \\
\hline $\begin{array}{l}\text { Methamphetamine } \\
\text { (desoxyephedrine) }^{c}\end{array}$ & SNDRA & ADHD, obesity & 1944 & 1971 & 1973 & USA, Turkey, Oman, Nigeria & Drug abuse, drug dependence & 4 \\
\hline Phendimetrazine & NDRA & & 1961 & 1979 & 1982 & Turkey & Drug abuse & 4 \\
\hline Phenmetrazine & NDRA & Obesity & 1956 & 1959 & 1982 & Turkey, Oman, Nigeria & Drug abuse & 4 \\
\hline Phentermine $e^{b, c}$ & NDRA & Obesity & 1959 & 1964 & 1981 & $\begin{array}{l}\text { Sweden, UAE, Mauritius, Turkey, Oman, } \\
\text { UK, Venezuela }\end{array}$ & Drug abuse & 4 \\
\hline $\begin{array}{l}\text { Phenylpropanolamine } \\
\text { (norpseudoephedrine) }\end{array}$ & NDRA & $\begin{array}{l}\text { Nasal decongestion, } \\
\text { obesity }\end{array}$ & 1947 & 1985 & 1987 & $\begin{array}{l}\text { Germany, Brazil, Malaysia, Singapore, } \\
\text { USA, Oman, Canada, Cuba, India }\end{array}$ & Hemorrhagic stroke & 4 \\
\hline
\end{tabular}


Table 1 List of anti-obesity drugs withdrawn from the market because of adverse drug reactions (Continued)

\begin{tabular}{|c|c|c|c|c|c|c|c|c|}
\hline Pipradrol & NDRI & $\begin{array}{l}\text { Obesity, narcolepsy, } \\
\text { ADHD }\end{array}$ & 1953 & 1968 & 1982 & USA, Turkey, Denmark, Venezuela & Drug abuse & 4 \\
\hline Pyrovalerone & NDRA & $\begin{array}{l}\text { Obesity, chronic } \\
\text { fatigue syndrome }\end{array}$ & 1974 & 1975 & 1979 & France & Drug abuse & 4 \\
\hline Rimonabant $^{c}$ & $\begin{array}{l}\mathrm{CB}_{1} \text { antagonist/ } \\
\text { inverse agonist }\end{array}$ & Obesity & 2006 & 2006 & 2007 & Europe, India & Psychiatric & 1 \\
\hline Sibutramine ${ }^{c}$ & SNRI & Obesity & 2001 & 2002 & 2002 & $\begin{array}{l}\text { EU; } 4 \text { Asian countries; Australia; Canada; } \\
\text { Mexico; New Zealand; USA }\end{array}$ & Cardiotoxicity, psychiatric & 4 \\
\hline
\end{tabular}

$\overline{A D H D}$ attention deficit hyperactivity disorder, $A D R$ adverse drug reaction, $C B_{1}$ cannabinoid 1 (receptors), EU European Union, NRA norepinephrine releasing agent, $N D R A$ norepinephrine-dopamine releasing agent, $N D R I$ norepinephrine-dopamine re-uptake inhibitor, SNDRA serotonin-norepinephrine-dopamine releasing agent, SNRI serotonin-norepinephrine re-uptake inhibitor, SRI serotonin re-uptake inhibitor, UAE United Arab Emirates

${ }^{a}$ Based on the Oxford Centre for Evidence-Based Medicine Levels of Evidence [17]. Level 1: systematic review of randomized trials, systematic review of nested case-control studies, Level 2: individual randomized trial or (exceptionally) observational study with dramatic effect; Level 3: non-randomized controlled cohort/follow-up study (post-marketing surveillance); Level 4: case-series, case-control, or historically controlled studies; Level 5: mechanism-based reasoning

${ }^{\mathrm{b}} \mathrm{Re}$-introduced in the EU based on long-standing legal action unrelated to either new safety or new efficacy information

'Reported to have caused deaths 
Table 2 Summary comparison of post-marketing withdrawal patterns of centrally acting anti-obesity medicinal products

\begin{tabular}{|c|c|c|c|c|}
\hline $\begin{array}{l}\text { Primary mode of } \\
\text { action at receptor } \\
\text { ending }\end{array}$ & $\begin{array}{l}\text { Primary reason } \\
\text { for withdrawal }\end{array}$ & $\begin{array}{l}\text { Median interval between } \\
\text { launch and first ADR } \\
\text { report }\end{array}$ & $\begin{array}{l}\text { Median interval between } \\
\text { first ADR report and } \\
\text { withdrawal }\end{array}$ & Statistical comparisons ${ }^{\mathrm{a}}$ \\
\hline $\begin{array}{l}\text { Neurotransmitter } \\
\text { re-uptake inhibition } \\
(n=8)\end{array}$ & $\begin{array}{l}\text { Cardiotoxicity: } n=7 \\
\text { Drug misuse: } n=1\end{array}$ & $\begin{array}{l}5.5 \text { years } \\
(\mathrm{IQR}=1.3 \text { to } 13.3 \text { years }\end{array}$ & $\begin{array}{l}1 \text { year } \\
\text { (IQR = } 0 \text { to } 12 \text { years })\end{array}$ & $\begin{array}{l}\text { Withdrawal due to cardiotoxicity significantly } \\
\text { more likely vs neurotransmitter releasers } \\
(P=0.0004)\end{array}$ \\
\hline $\begin{array}{l}\text { Neurotransmitter } \\
\text { release }(n=14)\end{array}$ & $\begin{array}{l}\text { Cardiotoxicity: } n=1 \\
\text { Drug abuse or } \\
\text { dependence: } n=12 \\
\text { Hemorrhagic stroke: } n=1\end{array}$ & $\begin{array}{l}17.5 \text { years } \\
\text { (IQR }=5.8 \text { to } 28 \text { years) }\end{array}$ & $\begin{array}{l}5 \text { years } \\
\text { (IQR }=2 \text { to } 16.3 \text { years) }\end{array}$ & $\begin{array}{l}\text { Withdrawal due to drug misuse significantly } \\
\text { more likely vs neurotransmitter re-uptake } \\
\text { inhibitors }(P=0.002)\end{array}$ \\
\hline
\end{tabular}

One centrally acting product, rimonabant, has been excluded from the comparisons because it is an antagonist and inverse agonist at cannabinoid C1 receptors aUsing Fisher's exact test; there was no significant difference between groups for proportion of psychiatric disturbances $(P=1.000)$

$A D R$ adverse drug reaction, $I Q R$ interquartile range

to be withdrawn because of drug abuse and dependence. When compared with our overall corpus of 462 medicinal products withdrawn from the market after 1950 [17], there was no significant difference in the proportion of case reports being used as evidence for withdrawal. The median interval to first reports of adverse reactions and first withdrawals was longer with the anti-obesity products (11 versus 3 years), but this is likely due to the smaller proportion of anti-obesity product approvals after 1976 compared with the overall data (the median interval to withdrawal for the products withdrawn since 1995 was 3 years). Furthermore, the intervals to withdrawal with more recent product launch are also consistent with the trend observed in the overall corpus.

The use of case reports as evidence for making withdrawal decisions in a majority of instances corroborates our previous findings that formal studies are seldom conducted when adverse drug reactions are suspected [18]. In addition, the fact that most of the withdrawn products were centrally acting anorectics suggests that use of this class of products in the treatment of obesity is associated with a negative benefit-to-harm balance over time (see Table 3 and Additional file 3). Furthermore, the discrepancy in withdrawal patterns across regulatory authorities indicates a lack of uniformity in harms assessment by different drug regulators, and also contributes to discrepancies in patterns of marketing authorizations of this class of products.

That the delays to reports of adverse reactions with time were shortened, albeit inconsistently, suggests an influence of better methods for detection of adverse drug reactions, improved transparency in the report of adverse drug events by trials investigators, or a combination of the two. However, the speed with which withdrawals occurred following reports of suspected adverse reactions with more recently launched drugs arouses suspicion of selective reporting of harms in the pre-marketing phase. The shorter intervals to withdrawals when deaths are reported suggest that regulatory authorities are quicker at making withdrawal decisions in these circumstances.

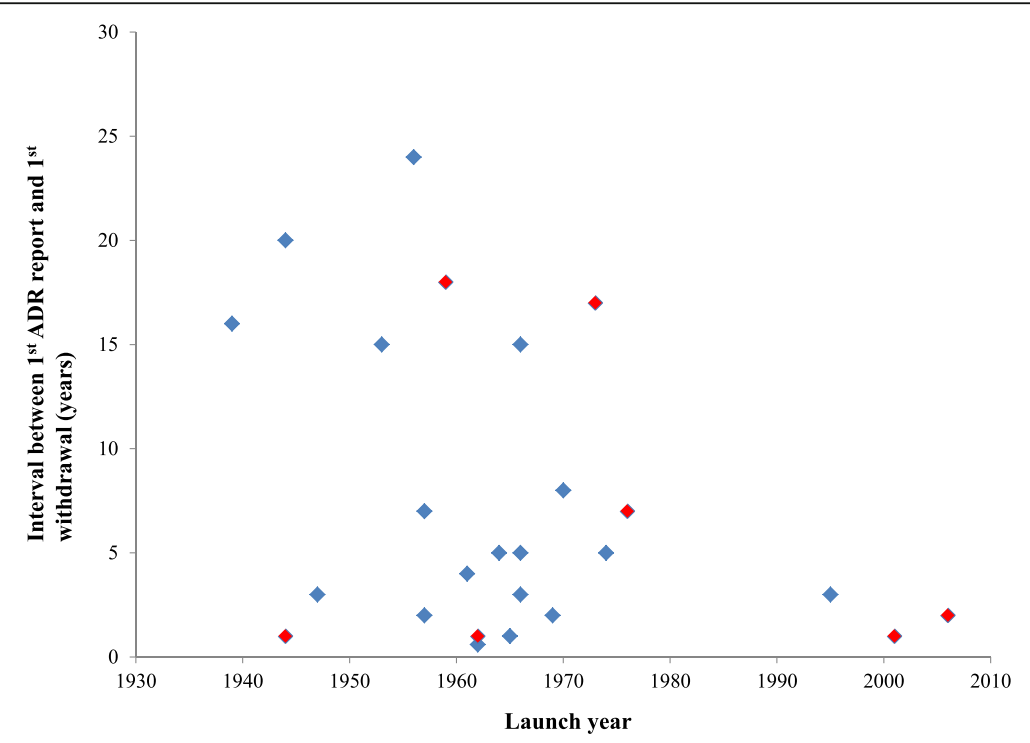

Fig. 1 Interval between first ADR reports and first withdrawals. The red boxes indicate products to which deaths were attributed 
Table 3 Profile of centrally acting anti-obesity products withdrawn because of associated deaths over the last 50 years

Aminorex

- First introduced in 1962

- Became available within 3 years of introduction as an over-the-counter weight loss pill

- Between 1965 and 1972, there was an alarming increase in the incidence of primary pulmonary hypertension [52]

- The pulmonary hypertension epidemic ended in 1972 following the withdrawal of aminorex from the market

Benfluorex

- Approved in 1976 as an add-on treatment in obese patients with diabetes mellitus

- Cases of valvulopathy attributed to its use began to appear from 2003

- Was withdrawn in 2009 following an epidemic of valvulopathy attributed to its use

- Several deaths reported

- To date, more than 3000 hospitalizations and at least 1300 deaths attributed to its use in France alone [53]

Fenfluramine

- First approved in in 1973

- Reports of pulmonary hypertension first appeared in 1981

- Several other case reports subsequently published

- Epidemiological studies showed an association between fenfluramine and pulmonary hypertension [54]

- Withdrawn worldwide in 1997

Methamphetamine (desoxyephedrine)

- First introduced in 1944

- Within 10 years of its introduction, cases of its misuse had been reported

- By the early 1970s, reports of its abuse as an anorectic were reported [55]

- Was withdrawn in the USA and other countries in 1973

- Several cases of cardiac abnormalities related to its abuse have subsequently been reported

Phentermine

- First approved in 1959

- Several cases of lung phospholipidosis in animals and humans reported thereafter

- Reports of death began to appear in 1974 [56]

- Withdrawn from most countries where it was marketed in 1981

- Still available for short-term management of obesity in the USA

Rimonabant

- Approved in Europe in 2006 for obesity treatment

- Within 1 year of approval, concerns were expressed about the risk of depression and suicide associated with its use [57]

- Five deaths attributed to its use in the UK [58]

- Was withdrawn in 2007

Sibutramine

- Approved in 1997 in the USA and Europe in 2001

- Within a year of its European approval, serious cardiovascular adverse reactions were reported, resulting in temporary withdrawal in Italy [59]

- Several cases of severe cardiovascular adverse reactions, including deaths, were subsequently reported [60]

- Withdrawn in Europe and USA in 2010

Fishman AP. 1999 [52]

Fournier A, Zureik M. 2012 [53]

Connolly HM, Crary JL, McGoon MD, Hensrud DD, Edwards BS, Edwards WD, Schaff HV. 1997 [54]

Ladewig D, Battegay R. 1971 [55]

Price K. 1974 [56]

Gadde KM. 2006 [57]

World Health Organization. 2008 [58]

Anonymous. 2002 [59]

Wooltorton E. 2002 [60]

\section{Comparison with existing literature}

Our findings are consistent with other published reports. A previous review reported that most anti-obesity treatments have been withdrawn from the market because of concerns about adverse reactions [14]. Two other reviews concluded that cardiovascular and psychiatric adverse reactions are major concerns with psychoactive anti-obesity drugs that have recently gained marketing approval from licensing authorities $[19,20]$. A recent analysis of serious adverse reactions reported to the EudraVigilance database also showed that cardiac and psychiatric disorders were the most common adverse reactions attributed to anti-obesity medicinal products [21]. The authors of another report concluded that lower doses of multiple chemical entities targeting different mechanistic pathways should be a priority in future drug development [1].

\section{Strengths and limitations}

To our knowledge, this is the first review that has systematically identified anti-obesity medicinal products withdrawn from the market because of adverse drug reactions. We comprehensively searched various sources of information in order to identify anti-obesity medicinal 
products that have been withdrawn, we accounted for the levels of evidence used in making withdrawal decisions, extracted data on the intervals between launch, adverse reactions reports, and withdrawals, and explored the trends in withdrawal over time. We also used statistical methods to explore and compare the patterns of withdrawal. However, we recognize some limitations. We may not have identified all countries in which products were withdrawn, and we do not have complete information about where all the products were marketed; indeed it is possible that some products were withdrawn in a few countries because those were the only places where they were marketed. In addition, we do not have information on the time lapse between the actual occurrence of an adverse reaction and the date the reaction appeared in the published literature, though we do not consider that such delays would have significantly influenced our findings. Finally, the intervals between launch, first adverse reaction reports, and first withdrawals were computed irrespective of where products were first introduced or where adverse reactions were first observed; however, some products were withdrawn in some countries because of adverse reactions reported in others irrespective of whether the product was first marketed in such countries.

\section{Implications for drug therapy}

Apart from two products (cyclovalone and iodinated casein), the products identified in the review had actions involving 5-hydroxytryptamine (5HT, serotonin). While agonist activity at $5 \mathrm{HT}_{2 \mathrm{~A}}$ receptors can cause psychiatric dysfunction [22], stimulation of $5 \mathrm{HT}_{2 \mathrm{~B}}$ receptors is associated with cardiac abnormalities, largely valvulopathies [23].The unfavourable benefit-to-harm balance of this class of products therefore appears to have led to the development of new chemical entities that target other mechanistic pathways. These include leptin sensitizers, glucagon-like peptide 1 (GLP-1) receptor agonists, islet amyloid polypeptide (IAPP), and neuropeptide Y [24]. Of note, several medicinal products with similar mechanisms of action to the withdrawn psychotropic antiobesity medications have been successfully used for treating other medical conditions, and they have not been withdrawn from the market. This may be because in those conditions their mechanisms of action are specifically targeted against abnormal pathways. For example, several analogues of amphetamine are available for treating attention deficit hyperactivity disorder (ADHD) and narcolepsy $[25,26]$.

There were no new approvals of anti-obesity medications during the 20 years from 1976 to 1995 . It is unclear what caused this hiatus; however, we observed a steep increase in the number of scientific publications relating obesity prevalence and treatment after the hiatus (PubMed trend; Additional file 4). The resurgence of new approval applications after the hiatus was not associated with a major shift in the development of drugs that affect neurotransmitters, but it is notable that no new drugs that cause neurotransmitter release have been marketed since 1974. This is consistent with the fact that of the nine medicinal products currently available for obesity management, all six (78\%) that exert their weight reducing actions through centrally acting mechanisms act via neurotransmitter release, rather than inhibition of re-uptake (see Table 4). This suggests that drug developers have largely abandoned the use of chemical entities that inhibit re-uptake in favour of releasing agents. However, the lack of long-term data on the safety of

Table 4 Anti-obesity drugs currently approved for use in at least one country

\begin{tabular}{|c|c|c|c|}
\hline Brand name & Active ingredient & Mechanism of action & Year approved \\
\hline Adipex-P, Ionamin & Phentermine & Precise mechanism unknown: norepinephrine-dopamine releasing agent & 1959 \\
\hline Alli, Xenical ${ }^{a}$ & Orlistat & Inhibits gastric and pancreatic lipases & 1999 \\
\hline Belviq $^{a}$ & Lorcaserin & Selective $5-\mathrm{HT}_{2 \mathrm{C}}$ receptor agonist & 2012 \\
\hline Contrave, Mysimba ${ }^{a}$ & Naltrexone + bupropion & $\begin{array}{l}\text { Bupropion: re-uptake inhibitor and releasing agent of norepinephrine and a } \\
\text { nicotinic acetylcholine receptor antagonist; naltrexone augments bupropion's } \\
\text { activation of proopiomelanocortin (POMC) }\end{array}$ & 2014 \\
\hline Didrex & Benzphetamine & Precise mechanism unknown: norepinephrine-dopamine releasing agent & 1960 \\
\hline Obezine & Phendimetrazine & Precise mechanism unknown: norepinephrine-dopamine releasing agent & 1961 \\
\hline Qsymia, Qnexa ${ }^{a}$ & Phentermine + topiramate & $\begin{array}{l}\text { The precise mechanism of action for both drugs is unknown: phentermine } \\
\text { is a norepinephrine-dopamine releasing agent; topiramate augments } \\
\text { gamma-aminobutyrate (GABA), inhibits a-amino-3-hydroxy-5-methyl-4- } \\
\text { isoxazolepropionic acid (AMPA)/kainate glutamate receptors, and inhibits } \\
\text { carbonic anhydrase }\end{array}$ & 2012 \\
\hline Saxenda, Victoza ${ }^{a}$ & Liraglutide & Glucagon-like peptide-1 receptor agonist & 2014 \\
\hline Tenuate Dospan & Diethylpropion & Precise mechanism unknown: norepinephrine-dopamine releasing agent & 1959 \\
\hline
\end{tabular}

${ }^{\mathrm{a} A p p r o v e d}$ for long-term treatment 
these products, especially with the more recent approvals, is of great concern. Indeed, psychiatric and cardiovascular adverse events have been reported as major concerns of recently approved products with centrally acting mechanisms [19].

Modest reduction in body weight has beneficial effects on short-term ( $\leq 1$ year) cardiovascular profile [27]. However, whether the weight losses generated by antiobesity medicinal products have beneficial effects on long-term cardiovascular outcome is unclear, largely because the follow-up duration of most clinical trials is not long enough to assess these benefits beyond the weight losses achieved [28]; indeed, one large long-term study $(n=5145$; median follow-up of 9.6 years) showed that weight reduction did not reduce the risk of adverse cardiovascular events in obese and overweight adults with type 2 diabetes [29]. In addition, the benefit of aggressive weight reduction in overweight and obese patients with cardiovascular decompensation (e.g. patients with heart failure) has been questioned, because this group of patients survives for a longer period at higher body weights [30]. Furthermore, more than one-third of the centrally acting products included in our review were withdrawn because their use was associated with adverse cardiovascular outcomes that are the health risks the use of the products were intended to reduce - an "obesity treatment paradox".

\section{Implications for future harms assessment and policy}

Although there have been revisions to regulatory guidance for the assessment of harms in anti-obesity drug trials [31,32], there are uncertainties about the extent to which these guidelines are applied when assessing trial results for new weight loss products whose actions are through central mechanisms. For example, lorcaserin, a $5 \mathrm{HT}_{2 \mathrm{C}}$ receptor agonist, was approved by the FDA based on the results of three pivotal trials [33-35], with discontinuation rates of $45 \%, 50 \%$, and $34 \%$, with mean differences in weight loss of only $3-3.6 \%$. Although two of the three trials met the FDA guidance for effectiveness ("The proportion of subjects who lose greater than or equal to 5 percent of baseline body weight in the activeproduct group is at least $35 \%$, is approximately double the proportion in the placebo-treated group, and the difference between groups is statistically significant") [32], the analysis was based on the per-protocol population for completers. Furthermore, the trials failed to meet the FDA's guidance for products for weight management, which sets clinical significance at 1 year as $5 \%$ weight loss with at least $80 \%$ power. Indeed, the FDA noted that baseline psychiatric history was limited in the clinical trials, discontinuations owing to nervous system and psychiatric disorders were higher with lorcaserin than with placebo, and the trials were not powered to detect cardiovascular adverse events [36]; these same concerns influenced the decision of the EMA in declining the product's approval application [37]. In addition, transcripts from the FDA showed that although members of the voting panel approved the product, many had concerns about cardiovascular harms [38]; it is of further concern that the post-marketing surveillance of the product is behind schedule [39].

Similarly, the approval of naltrexone plus bupropion (Contrave, Mysimba) by the FDA and EMA has been questioned by some authors because of the potential for severe harms that appear to outweigh the benefits $[40,41]$. In a recent large randomized trial there was a significantly increased risk of psychiatric disorders, and the cardiovascular profile of the product is uncertain [42]. These questionable approvals by regulatory authorities lend credence to the argument that an independent group of experts should be given responsibility for assessing harms [43]. The re-introduction of amfepramone (diethylpropion) and phentermine in Europe, based on a long-standing legal action, unrelated to new information on benefits or harms, is another case in point $[44,45]$.

The herbal weight loss medication Ephedra spp., which has agonist activity at $5 \mathrm{HT}$ and dopamine receptors and showed evidence of beneficial effects on body weight, was banned by the FDA in 2004 because of an increased risk of cardiovascular and psychiatric adverse reactions [46, 47]. That regulatory authorities removed this product from the market yet granted its "conventional analogues" marketing licences arouses suspicion of regulatory bias [48].

In addition to the above, several of the products that have been withdrawn by regulatory authorities are now marketed as non-prescription formulations, alone, or in combination over the counter, or via the Internet [49]. Indeed, there have been many reports of suspected adverse reactions attributed to such products $[7,50,51]$. There should be tougher legislative action against the promoting and marketing of such products.

\section{Conclusions}

We have identified 25 anti-obesity medications withdrawn after marketing over the past 60 years, 23 of which were centrally acting anorectics. Psychiatric disturbances, cardiotoxicity, or drug abuse and dependence accounted for more than $80 \%$ of withdrawals. Centrally acting products that caused release of monoamines were significantly more likely to be withdrawn because of adverse cardiovascular reactions, while monoamine re-uptake inhibitors were more likely to be withdrawn because of drug abuse and dependence. Greater transparency in the reporting of the harms by trial 
investigators should be encouraged. Individuals with vested interests could be excluded from panels that consider new drug approval applications.

\section{Additional files}

Additional file 1: Extended search lists of accessed sources used to identify anti-obesity medicinal products withdrawn from the market because of adverse drug reactions. (PDF $146 \mathrm{~kb}$ )

Additional file 2: Databases and selected texts used to identify withdrawn anti-obesity medications, their launch dates, dates of first adverse drug reaction reports, and withdrawals. (PDF $36 \mathrm{~kb}$ )

Additional file 3: Profiles of 23 centrally acting anti-obesity medicinal products withdrawn over the last 50 years because of adverse drug reactions. (PDF $246 \mathrm{~kb}$ )

Additional file 4: Publication trends* for scientific articles related to obesity prevalence and treatments over time. (PDF 16 kb)

\section{Abbreviations}

2,4-DNP: 2,4-dinitrophenol; 5HT: 5-hydroxytryptamine; ADHD: Attention deficit hyperactivity disorder; AMA: American Medical Association; EMA: European Medicines Agency; FDA: United States Food and Drug Administration; GLP-1: Glucagon-like peptide 1; IAPP: Islet amyloid polypeptide; IQR: Interquartile range; MAH: Marketing authorization holder; MHRA: UK Medicines and Healthcare products Regulatory Agency; WHO: World Health Organization;

\section{Acknowledgements}

IJO receives scholarship funding from the Clarendon Fund for the DPhil programme in Primary Care at the University of Oxford. CJH is supported by the National Institute for Health Research School for Primary Care Research.

\section{Funding}

This section is not applicable.

\section{Availability of data and materials}

Data are available in the publications and resources cited in the manuscript.

\section{Authors' contributions}

IJO was involved with devising the review method, conducting electronic and non-electronic searches, data extraction, data analysis and interpretation, and co-drafting of the manuscript. $\mathrm{CJH}$ was involved in devising the review method, data interpretation, and co-drafting of the manuscript. JKA was involved in devising the review method, conducting electronic and non-electronic searches, data extraction, data analysis and interpretation, and co-drafting of the manuscript. All authors read and approved the final manuscript.

\section{Competing interests}

$\mathrm{CJH}$ has received expenses and payments for media work from Channel 4 BBC, FreshOne TV productions, and the Guardian. He has received expenses from the WHO and the US FDA, holds grant funding from the NIHR, the NIHR School of Primary Care Research, The Wellcome Trust, and the WHO. In addition, he is an expert witness in an ongoing medical device legal case and has received payment from BUPA for analysing and appraising guidelines and income from the publication of a series of toolkit books published by Blackwell. On occasion he receives expenses for teaching EBM and is paid for NHS GP work in the out of hours service in Oxford. He is also a director of CEBMi, which produces an iphone application with the BMJ, but receives no payment for this activity.

JKA has edited textbooks on adverse drug reactions, including some of the texts used in this systematic review; he is President Emeritus and an Honorary Fellow of the British Pharmacological Society, a member of a NICE technology appraisal committee, a member of the advisony board of the British National Formulary, an Honorary Fellow of the Faculty of Pharmaceutical Medicine, and chair of the British Pharmacopoeia Commission's Expert Advisory Group on Nomenclature. However, the opinions expressed in this article are not necessarily shared by those organizations or their other members. IJO has no competing interests to declare.

\section{Consent for publication}

This section is not applicable.

Ethics approval and consent to participate

This section is not applicable.

\section{Author details}

${ }^{1}$ Nuffield Department of Primary Care Health Sciences, University of Oxford, Centre for Evidence-Based Medicine, Gibson Building, Radcliffe Observatory Quarter, Oxford OX2 6GG, UK. ${ }^{2}$ Nuffield Department of Primary Care Health Sciences, University of Oxford, Centre for Evidence-Based Medicine, Radcliffe Primary Care Building, Radcliffe Observatory Quarter, Oxford, UK.

Received: 13 August 2016 Accepted: 27 October 2016

Published online: 29 November 2016

References

1. Rodgers RJ, Tschöp MH, Wilding JP. Anti-obesity drugs: past, present and future. Dis Model Mech. 2012;5(5):621-6.

2. Cawley J, Meyerhoefer C, Biener A, Hammer M, Wintfeld N. Savings in medical expenditures associated with reductions in body mass index among US adults with obesity, by diabetes status. Pharmacoeconomics. 2015:33(7):707-22

3. Butland B, Jebb S, Kopelman P, McPherson K, Thomas S, Mardell J, Parry V. Tackling obesities: future choices - project report. 2nd ed. London: Foresight Programme of the Government Office for Science; 2007. https:// www.gov.uk/government/uploads/system/uploads/attachment_data/file/ 287937/07-1184x-tackling-obesities-future-choices-report.pdf. Accessed 11 Nov 2015

4. World Health Organisation. Obesity and overweight. Fact sheet No.311 Updated January 2015. www.who.int/mediacentre/factsheets/fs311/en/. Accessed 20 Mar 2016

5. Dietz WH, Baur LA, Hall K, Puhl RM, Taveras EM, Uauy R, Kopelman P. Management of obesity: improvement of health-care training and systems for prevention and care. Lancet. 2015;385(9986):2521-33.

6. Tainter ML, Stockton AB, Cutting WC. Use of dinitrophenol in obesity and related conditions. A progress report. JAMA. 1933;101:1472-5.

7. Grundlingh J, Dargan PI, El-Zanfaly M, Wood DM. 2,4-dinitrophenol (DNP): a weight loss agent with significant acute toxicity and risk of death. J Med Toxicol. 2011;7(3):205-12

8. Halford JCG. Appetite suppressants. Encyclopedia of psychopharmacology. 2013. doi: 10.1007/978-3-642-27772-6_110-2. Accessed 4 Mar 2016.

9. Colman E. Anorectics on trial: a half century of federal regulation of prescription appetite suppressants. Ann Intern Med. 2005;143(5):380-5.

10. Council of Pharmacy and Chemistry of the American Medical Association. New and nonofficial remedies. Philadelphia: JB Lippincott; 1946. p. 281.

11. Bray GA. Medical treatment of obesity: the past, the present and the future. Best Pract Res Clin Gastroenterol. 2014;28(4):665-84.

12. Melnikova I, Wages D. Anti-obesity therapies. Nat Rev Drug Discov. 2006: 5(5):369-70

13. Daneschvar HL, Aronson MD, Smetana GW. FDA Approved Anti-obesity Drugs in the United States. Am J Med. 2016;129(8):879. e1-6.

14. Kang JG, Park CY. Anti-obesity drugs: a review about their effects and safety. Diabetes Metab J. 2012;36(1):13-25.

15. OCEBM Levels of Evidence Working Group. The Oxford 2011 Levels of Evidence. Oxford Centre for Evidence-Based Medicine. 2016. http://www. cebm.net/ocebm-levels-of-evidence/.

16. WHO Collaborating Centre for Drug Statistics Methodology. Complete ATC DDD Index 2008. www.whocc.no/atc_ddd_index/. Accessed 21 Apr 2013.

17. Onakpoya IJ, Heneghan CJ, Aronson JK. Post-marketing withdrawal of 462 medicinal products because of adverse drug reactions: a systematic review of the world literature. BMC Med. 2016;14:10. doi:10.1186/s12916-016-0553-2.

18. Onakpoya IJ, Heneghan CJ, Aronson JK. Delays in the post-marketing withdrawal of drugs to which deaths have been attributed: a systematic investigation and analysis. BMC Med. 2015:13:26. doi:10.1186/s12916-0140262-7

19. Hainer V Aldhoon-Hainerová I. Tolerability and safety of the new antiobesity medications. Drug Saf. 2014;37(9):693-702.

20. Cheung BM, Cheung TT, Samaranayake NR. Safety of antiobesity drugs. Ther Adv Drug Saf. 2013:4(4):171-81. 
21. Aagaard L, Hallgreen CE, Hansen EH. Serious adverse events reported for antiobesity medicines: postmarketing experiences from the EU adverse event reporting system EudraVigilance. Int J Obes (Lond). 2016. doi:10.1038/ ijo.2016.135.

22. de Angelis L. 5-HT2A antagonists in psychiatric disorders. Curr Opin Investig Drugs. 2002:3(1):106-12.

23. Rothman RB, Baumann MH, Savage JE, Rauser L, McBride A, Hufeisen SJ, Roth BL. Evidence for possible involvement of $5-\mathrm{HT}(2 \mathrm{~B})$ receptors in the cardiac valvulopathy associated with fenfluramine and other serotonergic medications. Circulation. 2000;102(23):2836-41.

24. Kim GW, Lin JE, Blomain ES, Waldman SA. Antiobesity pharmacotherapy: new drugs and emerging targets. Clin Pharmacol Ther. 2014;95(1):53-66.

25. Hodgkins P, Shaw M, Coghill D, Hechtman L. Amfetamine and methylphenidate medications for attention-deficit/hyperactivity disorder: complementary treatment options. Eur Child Adolesc Psychiatry. 2012;21(9):477-92.

26. Mignot EJ. A practical guide to the therapy of narcolepsy and hypersomnia syndromes. Neurotherapeutics. 2012;9(4):739-52.

27. Schwingshackl L, Dias S, Hoffmann G. Impact of long-term lifestyle programmes on weight loss and cardiovascular risk factors in overweight/ obese participants: a systematic review and network meta-analysis. Syst Rev. 2014:3:130. doi:10.1186/2046-4053-3-130

28. Lawlor DA, Chaturvedi N. Treatment and prevention of obesity-are there critical periods for intervention? Int J Epidemiol. 2006;35(1):3-9.

29. Look AHEAD. Research Group, Wing RR, Bolin P, Brancati FL, Bray GA, Clark JM. Cardiovascular effects of intensive lifestyle intervention in type 2 diabetes. N Engl J Med. 2013;369(2):145-54.

30. Charakida M, Finer N. Drug treatment of obesity in cardiovascular disease. Am J Cardiovasc Drugs. 2012;12(2):93-104.

31. European Medicines Agency. Guideline on clinical evaluation of medicinal products used in weight control. 2014. www.ema.europa.eu/docs/en_GB/ document_library/Scientific_guideline/2014/07/WC500170278.pdf. Accessed 11 Jan 2016.

32. US Food and Drug Administration. FDA guidance for industry. Developing products for weight management. 2007. www.fda.gov/downloads/Drugs/ \%E2\%80\%A6/Guidances/ucm071612.pdf. Accessed 11 Jan 2016.

33. Fidler MC, Sanchez M, Raether B, Weissman NJ, Smith SR, Shanahan WR, et al. A one-year randomized trial of lorcaserin for weight loss in obese and overweight adults: the BLOSSOM trial. J Clin Endocrinol Metab. 2011;96(10): 3067-77.

34. Smith SR, Weissman NJ, Anderson CM, Sanchez M, Chuang E, Stubbe S, et al. Multicenter, placebo-controlled trial of lorcaserin for weight management. N Engl J Med. 2010;363(3):245-56

35. O'Neil PM, Smith SR, Weissman NJ, Fidler MC, Sanchez M, Zhang J. Randomized placebo-controlled clinical trial of lorcaserin for weight loss in type 2 diabetes mellitus: the BLOOM-DM study. Obesity (Silver Spring). 2012; 20(7):1426-36.

36. FDA Briefing Document. NDA 22529. Lorcaserin Hydrochloride Tablets, 10 mg.Sponsor: Arena Pharmaceuticals. Endocrinologic and Metabolic Drugs Advisory Committee Meeting - May 10, 2012. www.fda.gov/ downloads/AdvisoryCommittees/CommitteesMeetingMaterials/Drugs/ EndocrinologicandMetabolicDrugsAdvisoryCommittee/UCM303198.pdf. Accessed 29 Apr 2016

37. European Medicines Agency. Withdrawal of the marketing authorisation application for Belviq (lorcaserin). 2013. www.ema.europa.eu/docs/en_GB/ document_library/Medicine_QA/2013/05/WC500143811.pdf. Accessed 26 Apr 2016.

38. Miller LE. Lorcaserin for weight loss: insights into US Food and Drug Administration approval. J Acad Nutr Diet. 2013;113(1):25-30.

39. Woloshin S, Schwartz LM. The new weight-loss drugs, lorcaserin and phentermine-topiramate: slim pickings? JAMA Intern Med. 2014;174(4):615-9.

40. No authors listed. Naltrexone + bupropion (Mysimba). Too risky for only modest weight loss. Prescrire Int. 2015;24(164):229-33.

41. Hawkes N. Approval of antiobesity drug is "major regression for patients' safety", says health watchdog. BMJ. 2014;349:g7805. doi:10.1136/bmj.g7805

42. Nissen SE, Wolski KE, Prcela L, Wadden T, Buse JB, Bakris G, Perez A, Smith SR. Effect of naltrexone-bupropion on major adverse cardiovascular events in overweight and obese patients with cardiovascular risk factors: a randomized clinical trial. JAMA. 2016:315(10):990-1004.

43. Fontanarosa PB, Rennie D, DeAngelis CD. Postmarketing surveillance-lack of vigilance, lack of trust. JAMA. 2004;292(21):2647-50.
44. Royal College of Physicians of London. Anti-obesity drugs. Guidance on appropriate prescribing and management. April 2003. cdn.shopify.com/s/ files/1/0924/4392/files/anti-obesity_reportweb.pdf. Accessed 21 Mar 2016.

45. Judgment of the Court of First Instance (Second Chamber, extended composition) of 26 November 2002. Artegodan GmbH and Others v Commission of the European Communities. ec.europa.eu/health/files/ pharmacos/docs/doc2003/judg-2002_11_26_anorectics_en.pdf. Accessed 28 Apr 2016.

46. Shekelle PG, Hardy ML, Morton SC, Maglione M, Mojica WA, Suttorp MJ, et al. Efficacy and safety of ephedra and ephedrine for weight loss and athletic performance: a meta-analysis. JAMA. 2003;289(12):1537-45.

47. Food and Drug Administration, HHS. Final rule declaring dietary supplements containing ephedrine alkaloids adulterated because they present an unreasonable risk. Fed Regist. 2004;69(28):6787-854.

48. Abraham J. Science, politics, and the pharmaceutical industry: controversy and bias in drug regulation. New York: St. Martin's Press; 1995.

49. Cohen PA, Goday A, Swann JP. The return of rainbow diet pills. Am J Public Health. 2012;102(9):1676-86.

50. Pamukcu Gunaydin G, Dogan NO, Levent S, Kurtoglu CG. Herbal weight loss pill overdose: sibutramine hidden in pepper pill. Case Rep Emerg Med. 2015;2015:213874. doi:10.1155/2015/213874

51. EMCDDA-Europol. Dangerous synthetic drugs hit the EU market. 2014. www. emcdda.europa.eu/news/2014/europol-emcdda1. Accessed 21 Sept 2015.

52. Fishman AP. Aminorex to fen/phen: an epidemic foretold. Circulation. 1999;99(1):156-61.

53. Fournier A, Zureik M. Estimate of deaths due to valvular insufficiency attributable to the use of benfluorex in France. Pharmacoepidemiol Drug Saf. 2012;21(4):343-51.

54. Connolly HM, Crary JL, MCGoon MD, Hensrud DD, Edwards BS, Edwards WD, Schaff HV. Valvular heart disease associated with fenfluramine-phentermine. N Engl J Med. 1997;337(9):581-8.

55. Ladewig $D$, Battegay $R$. Abuse of anorexics with special reference to newer substances. Int J Addict. 1971;6(1):167-72.

56. Price K. Case notes: phentermine. Bull Int Assoc Foren Toxicol. 1974;10(1):12.

57. Gadde KM. Effect of rimonabant on weight and cardiometabolic risk factors. JAMA. 2006;296(6):649-50; author reply 650-1.

58. World Health Organization. Rimonabant: reports of serious ADRs. WHO Pharmaceuticals Newsletter 2008, No. 3:7. http://www.who.int/medicines/ publications/newsletter/2008news3.pdf.

59. Anonymous. Italy suspends sibutramine licence. Pharm J. 2002;268(7190): 385-91.

60. Wooltorton E. Obesity drug sibutramine (Meridia): hypertension and cardiac arrhythmias. CMAJ. 2002;166(10):1307-8.

\section{Submit your next manuscript to BioMed Central and we will help you at every step:}

- We accept pre-submission inquiries

- Our selector tool helps you to find the most relevant journal

- We provide round the clock customer support

- Convenient online submission

- Thorough peer review

- Inclusion in PubMed and all major indexing services

- Maximum visibility for your research

Submit your manuscript at www.biomedcentral.com/submit 